\title{
Genetic and phenotypic trends for age at first calving and milk yield and compositions in Holstein dairy cows
}

\author{
Navid Ghavi Hossein-Zadeh \\ Department of Animal Science, Faculty of Agriculture, University of Guilan, Rasht, Iran
}

\begin{abstract}
Calving records from the Animal Breeding Center of Iran collected from January 1990 to December 2007 and comprising 207106 first calving events of Holsteins from 2506 herds were analysed using linear sire models to estimate genetic trends for age at first calving (AFC) and milk traits. Genetic trends were obtained by regressing yearly mean estimates of breeding values on year of birth. In general, there were decreasing genetic trends for AFC, fat percentage and protein percentage over the years but there were increasing genetic trends for milk yield, mature-equivalent milk yield, fat yield, mature-equivalent fat yield, protein yield and mature-equivalent protein yield over the years. On the other hand, there was a decreasing phenotypic trend for AFC but estimates of phenotypic trends were positive for milk yield and compositions over the years. It seems that the decline in calving age in this study over time resulted primarily from increased turnover rate and increased culling of heifers that failed to get pregnant. On the other hand, increasing trend for yield traits over time in this study indicated that Iranian dairy producers were successful in choosing progressively better semen and sires from imported and local sources over the years.
\end{abstract}

Keywords: dairy cow, age at first calving, milk yield, phenotypic trend, genetic trend

\section{Zusammenfassung}

\section{Genetische und phänotypische Trends für Erstkalbealter, Milchleistung und Milchzusammensetzung bei Holstein Kühen}

Vom Januar 1990 bis Dezember 2007 wurden vom iranischen Tierzuchtzentrum Kalbungsberichte gesammelt. 207106 Erstkalbungen von 2506 Holsteinherden wurden anhand des linearen Vatermodells ausgewertet, um die genetischen Trends bezüglich des Erstkalbealters (AFC) und die Milcheigenschaften abzuschätzen. Die genetischen Trends wurden durch jährliche mittlere Regressionsabschätzungen von Zuchtwerten im Jahr der Geburt erhalten. Allgemein nahmen über die Jahre die genetischen Trends für AFC, Fettprozente und Proteinprozente ab, aber die genetischen Trends für Milchleistung, Fettgehalt und Proteingehalt zu.

Andererseits bestand ein abnehmender phänotypischer Trend für AFC, aber die Abschätzungen phänotypischer Trends waren über die Jahre für Milchleistung und Milchzusammensetzungen positiv. Es scheint, dass das Sinken des Erstkalbealter im Wesentlichen mit einer erhöhten Reproduktionsrate sowie verstärkter Selektion nicht 
trächtig werdennder Färsen im Zusammenhang steht. Anderseits zeigten die zunehmenden Trends für die Leistungsmerkmale, dass die iranischen Milchproduzenten bei der Auswahl von Sperma und Zuchtbullen aus importierten und heimischen Quellen Erfolg hatten.

Schlüsselwörter: Milchkuh, Erstkalbealter, Milchleistung, phänotypischer Trend, genetischer Trend

\section{Introduction}

Estimation of genetic trends is necessary to monitor and evaluate selection programs. Evaluation of important traits other than milk yield should provide dairy producers with more useful information upon which to base their genetic decisions (Mahoney et al. 1986). Age at first calving (AFC) includes the period that a cow needs to reach maturity and to reproduce for the first time. Age at first calving is a one of the many factors affecting farm profitability, through the direct cost of rearing heifers (Tozer \& Heinrichs 2001) as well as its potential effect on subsequent performance (Pirlo et al. 2000, Bewley et al. 2001, Nilforooshan \& Edriss 2004, Sawa \& Krezel-Czopek 2009). A younger age at first calving is beneficial in that it can potentially lead to a reduction in rearing costs (Tozer \& Heinrichs 2001) as well as an earlier return on investment. Nonetheless, rearing costs may be greater when seeking to calve at a younger age. Furthermore, a positive association between age at first calving and subsequent performance has been shown in previous studies (Dobos et al. 2004) which may affect any potential benefits of earlier calving. Nilforooshan and Edriss (2004) reported a non-linear association between age at first calving and first lactation milk yield in Iranian Holsteins with maximum milk yield achieved in heifers calving at 24 months of age; Pirlo et al. (2000) documented an increase in milk yield with age at first calving from 20 to 36 months of age in Italian Holsteins. Age at first calving has also been shown to influence calving performance (Ettema \& Santos 2004), fertility (Ettema \& Santos 2004) and longevity (Dürr et al. 1999, Ojango et al. 2005, Sawa \& Bogucki 2010).

Three USDA studies (USDA 2002b) on dairy health and management practices were compiled based on data from US herds in 1991, 1996 and 2002 that represented 83 to $85 \%$ of US cows. Mean age at first calving within herd declined slightly from 25.9 months in 1991 to 25.4 months in 2002 and declined from 25.8 to 25.0 months when weighted for cow numbers. Mean age at first calving in 2002 was inversely related to herd size (USDA 2002a) and within herd was 25.5 months when herd size was $<100$ cows but only 24.6 months when herd size was $\geq 500$ cows. Other studies have reported decreasing ages at first calving for dairy populations in The Netherlands (KNRS 2005) and Spain (González-Recio et al. 2004). Also there were several reports of genetic trends for milk yield but there were scarce estimates of genetic trends for AFC in the literature. Therefore, the objective of this study was to document genetic trends in AFC and productive traits of the first lactation Holstein dairy cows in Iran over 18-year period (1990-2007), using sire model analyses. 


\section{Material and methods}

\section{Data set}

Calving records from the Animal Breeding Center of Iran, collected from January 1990 to December 2007 and comprising 207106 first lactation Holstein calving events from 2506 herds were included in the data set. The herds used in this study are among the purebred Holsteins which are managed under conditions similar to most other developed countries and are under official performance and pedigree recording. The data included animal registration number, herd, calving date, parity, calving age, days in milk, adjusted milk yield (MY), mature equivalent milk yield (MEMY), adjusted fat yield (FY), adjusted fat percentage (FPER), mature equivalent fat yield (MEFY), adjusted protein yield (PY), adjusted protein percentage (PPER) and mature equivalent protein yield (MEPY). The pedigree information used in this study was extracted from the database used for the national genetic evaluation of dairy traits in Iran, which had been provided by the Animal Breeding Center of Iran and reported by Ghavi Hossein-Zadeh et al. (2009) in previous study. Outliers and out of range productive records were deleted from the analyses. Age at calving was required to be between 20 and 40 months in lactation one. Only records from the first parity that had data for all production traits were kept. Months of birth were grouped into four seasons: January through March (winter), April through June (spring), July through September (summer), and October through December (fall).

\section{Statistical models of analysis}

The fixed effects included in the models of analysis were determined from a preliminary analysis where the effects were statistically significant with a linear fixed effects model analysed with procedure GLM of SAS (SAS 2002). Level of significance for the inclusion of effects into the model of analysis was $P<0.05$. The final model for AFC included the fixed class effects of herd-year-season of calving and additive genetic effect of sire. Also, the final model for productive traits included the fixed class effects of herd-year-season of calving, the linear covariate effect of age at calving and additive genetic effect of sire. The following sire model was fitted to estimate genetic parameters for AFC and productive traits:

$$
y=X b+Z_{s} s+e
$$

where $y$ is a $\mathrm{N} \times 1$ vector of observations, $\boldsymbol{b}$ denotes the fixed effects in the model with association matrix $X, s$ is the vector of additive genetic effects of sires with the incidence matrix $Z_{s}$ and $e$ denotes the vector of residual effects.

\section{Genetic analyses}

The linear sire model analyses were run using a restricted maximum likelihood method and average information algorithm (AIREML) of the MATVEC program (Wang et al. 2001) to obtain genetic parameters of AFC and productive traits. Genetic trends were obtained by regressing yearly mean estimates of breeding values on year of birth. Also, phenotypic trends were estimated using the linear regression of average phenotypic values on calving year. 


\section{Results and discussion}

Summary statistics for AFC and milk yield and compositions are shown in Table 1. Also, estimates of genetic and phenotypic trends for AFC and productive traits in Holstein dairy cows are presented in Table 2 . In general, there were decreasing genetic trends for AFC, fat percentage and protein percentage over the years but there were increasing genetic trends for adjusted milk yield, mature equivalent milk yield, adjusted fat yield, mature equivalent fat yield, adjusted protein yield and mature equivalent fat yield over the years. On the other hand, there was a decreasing phenotypic trend for AFC but estimates of phenotypic trends were positive for milk yield and compositions over the years (Table 2).

Table 1

Summary statistics for AFC and productive traits in Holstein dairy cows from 1990 to 2007

\begin{tabular}{lrrr}
\hline Trait & $\mathrm{N}$ & Mean & \multicolumn{1}{c}{$\mathrm{SD}$} \\
\hline Age at first calving, months & 204232 & 26.48 & 4.64 \\
Adjusted milk yield, $\mathrm{kg}$ & 207106 & 6535.99 & 1489.58 \\
Mature equivalent milk yield, $\mathrm{kg}$ & 207106 & 7503.26 & 1729.10 \\
Adjusted fat yield, kg & 189609 & 206.76 & 51.65 \\
Fat percentage & 189609 & 3.19 & 0.51 \\
Mature equivalent fat yield, $\mathrm{kg}$ & 189609 & 237.32 & 59.74 \\
Adjusted protein yield, $\mathrm{kg}$ & 92349 & 216.53 & 39.35 \\
Protein percentage & 92349 & 3.10 & 0.26 \\
Mature equivalent protein yield, $\mathrm{kg}$ & 92349 & 249.12 & 45.46 \\
\hline
\end{tabular}

Table 2

Estimates of genetic and phenotypic trends $( \pm \mathrm{SE})$ for AFC and milk yield and compositions in Holstein dairy cows*

\begin{tabular}{lcc}
\hline Trait & \multicolumn{2}{c}{ Trend } \\
& Genetic & Phenotypic \\
\hline Age at first calving, month & $-0.013 \pm 0.005$ & $-0.083 \pm 0.013$ \\
Adjusted milk yield, kg & $4.205 \pm 1.105$ & $136.4 \pm 4.93$ \\
Mature equivalent milk yield, kg & $4.428 \pm 1.137$ & $160.5 \pm 5.69$ \\
Adjusted fat yield, kg & $0.051 \pm 0.023$ & $5.062 \pm 0.34$ \\
Fat percentage & $-0.001 \pm 0.0001$ & $0.011 \pm 0.003$ \\
Mature equivalent fat yield, kg & $0.047 \pm 0.027$ & $5.957 \pm 0.39$ \\
Protein yield, kg & $0.053 \pm 0.024$ & $5.429 \pm 0.97$ \\
Protein percentage & $-0.001 \pm 0.0001$ & $0.011 \pm 0.009$ \\
Mature equivalent protein yield, $\mathrm{kg}$ & $0.055 \pm 0.024$ & $6.401 \pm 1.13$ \\
\hline
\end{tabular}

${ }^{*}$ All estimates were significant at $P<0.05$.

Phenotypic trend and mean estimated breeding values for AFC by year of birth are shown in Figure 1. There was an increasing genetic trend for AFC from 1992 to 1997 but there was a decreasing genetic trend for AFC from 1998 onwards. Also, there was a decreasing phenotypic trend for AFC from 1996 to 2007. Mean estimated breeding values for MY, FY, MEMY and FPER by year of birth are shown in Figure 2. In addition, mean estimated breeding values for MEFY, PY, PPER and MEPY by year of birth are presented in Figure 3. There was an increasing trend for the mean estimated breeding values of MY, MEMY, FY, PY, MEPY and MEFY from 1998 to 


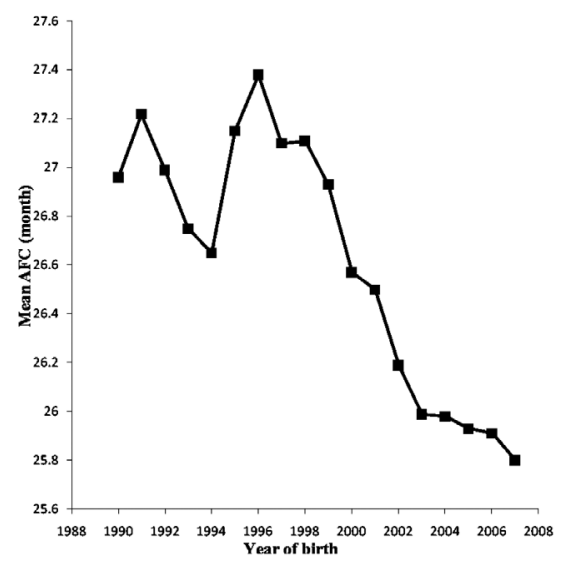

$1 \mathrm{a}$

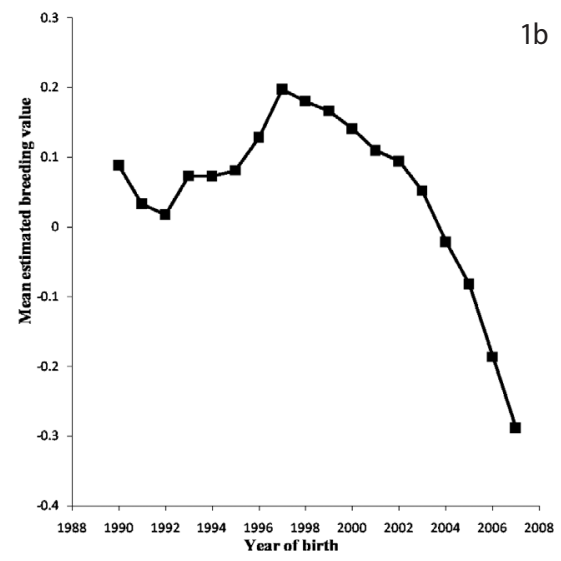

Figure 1

Phenotypic trend (1a) and mean estimated breeding values (1b) for AFC by year of birth in Holstein dairy cows
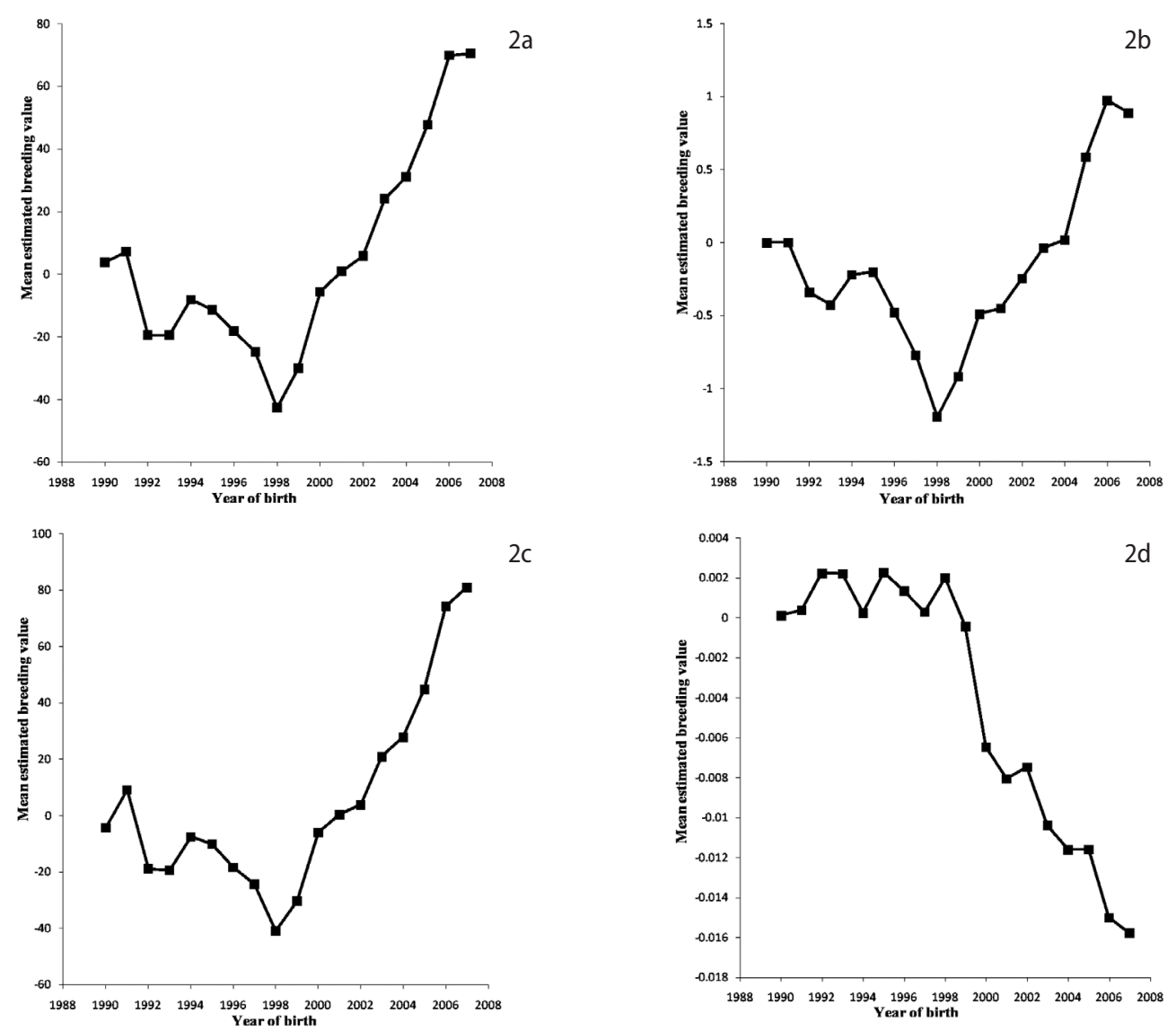

Figure 2

Mean estimated breeding values for MY (2a), FY (2b), MEMY (2c) and FPER (2d) by year of birth in Holstein dairy cows 

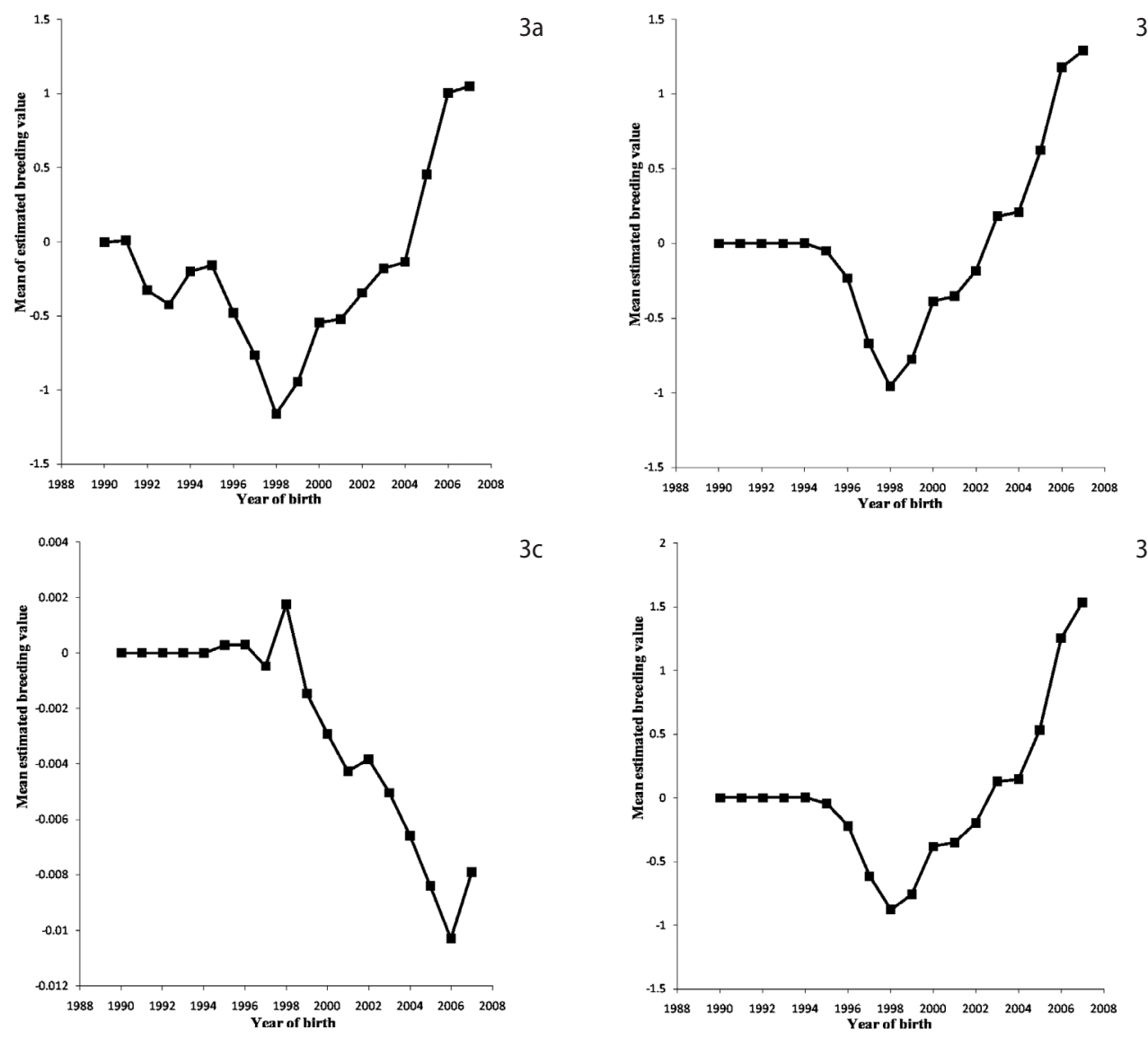

Figure 3

Mean estimated breeding values for MEFY (3a), PY (3b), PPER (3c) and MEPY (3d) by year of birth in Holstein dairy cows

2007, but a decreasing genetic trend was observed for FPER and PPER from 1998 onwards (Figures 2 and 3). Phenotypic trends of MY, MEMY, FY and MEFY by year of birth are shown in Figure 4. Also, phenotypic trends of PY, MEPY, FPER and PPER by year of birth are presented in Figure 5. Phenotypic means of MY, MEMY, FY and MEFY increased over the years. Phenotypic means of FPER had a large variation but there was an increasing trend from 1997 onwards. On the other hand, there was an increasing phenotypic trend for PY and MEPY from 1994 to 2007. For PPER, there was an increase in the means of PPER from 1991 to 1995, but there was no obvious variation in the concentrations of PPER thereafter.

Similar to the current results, Vergara et al. (2009) reported trend was negative for predicted cow yearly means for AFC in an Angus-Blanco Orejinegro-Zebu multibreed cattle population. Consistent with the results of this study, Hare et al. (2006) reported the decline in calving age across years for first parity dairy breeds in the United States. The decline in calving age in this study over time resulted primarily from increased turnover rate and increased culling of heifers that failed to get pregnant. Also, the decreases in AFC might represent earlier 


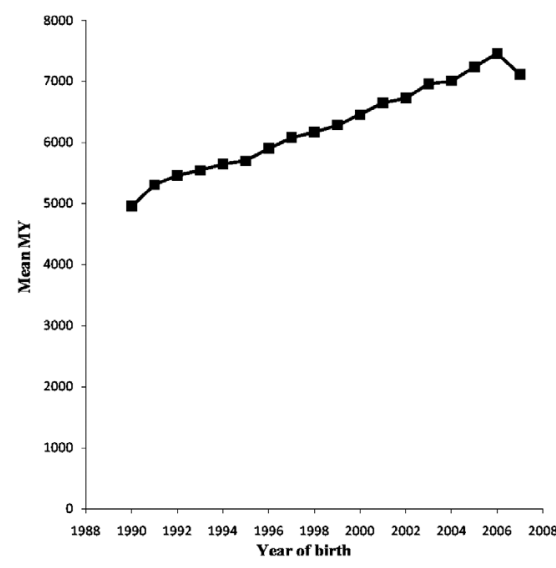

$4 a$
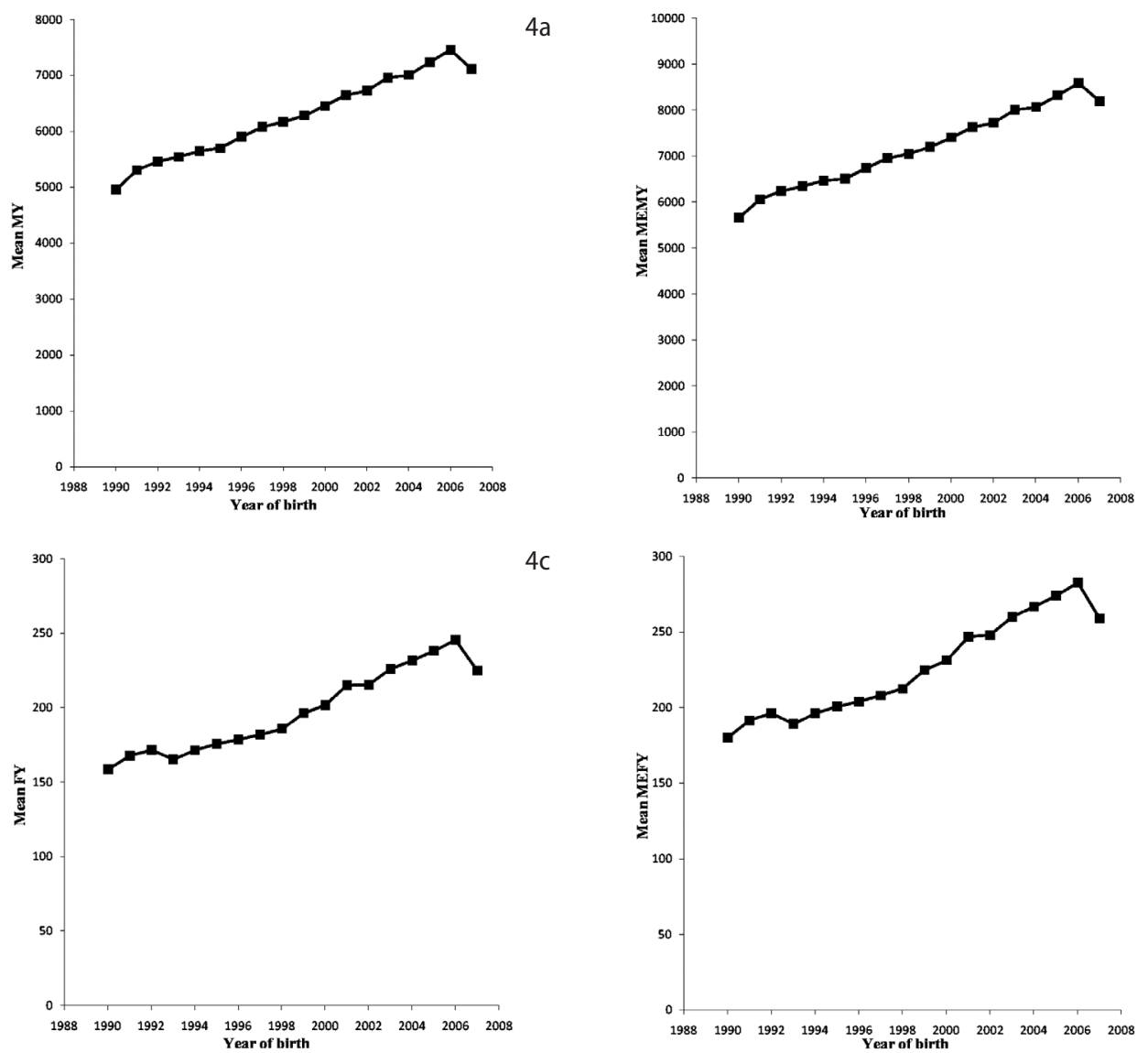

$4 c$

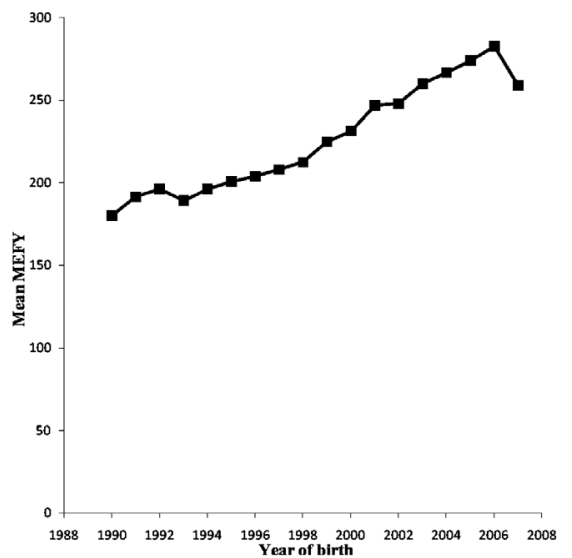

Figure 4

Phenotypic trends of MY (4a), MEMY (4b), FY (4c) and MEFY (4d) by year of birth in Holstein dairy cows

maturity from better calf-raising practices or from intense selection for high milk yield during the first parity. Similar reductions in age at first calving were also found in The Netherlands (Nederlands Rundvee Syndicaat 2005) and Spain (González-Recio et al. 2004).

Elzo et al. (2004) reported upward trends between 1990 and 2000 existed for mature equivalent milk yield and mature equivalent fat yield and a downward trend for MEPY in the Chilean multibreed dairy cattle population. Also, Abdallah \& McDaniel (2000) reported the greatest genetic changes were after 1980 (FCM, $94.7 \mathrm{~kg} /$ year; fat yield, $3.46 \mathrm{~kg} /$ year) in North Carolina experimental dairy herds. Similar to the current results, Katkasame et al. (1996) reported positive genetic and phenotypic trends for adjusted milk and fat yields but negative genetic and phenotypic trends for fat percentage in dairy cows in Thailand. Michailowskaja et al. (2001) reported a substantial increase in quantity traits, whereas a negative trend has been observed for the milk content merits. Mohsen et al. (2000) studied the genetic and phenotypic trends in estimated transmitting ability on Friesian herds raised in Egypt and Germany and concluded that sires used in the later years were 


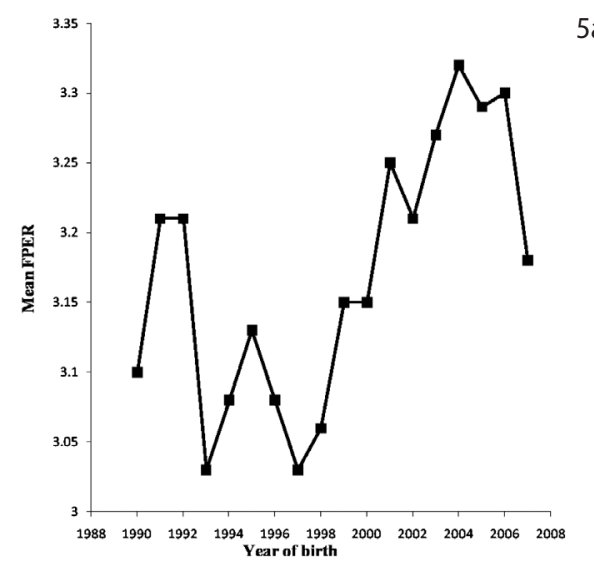

$5 a$
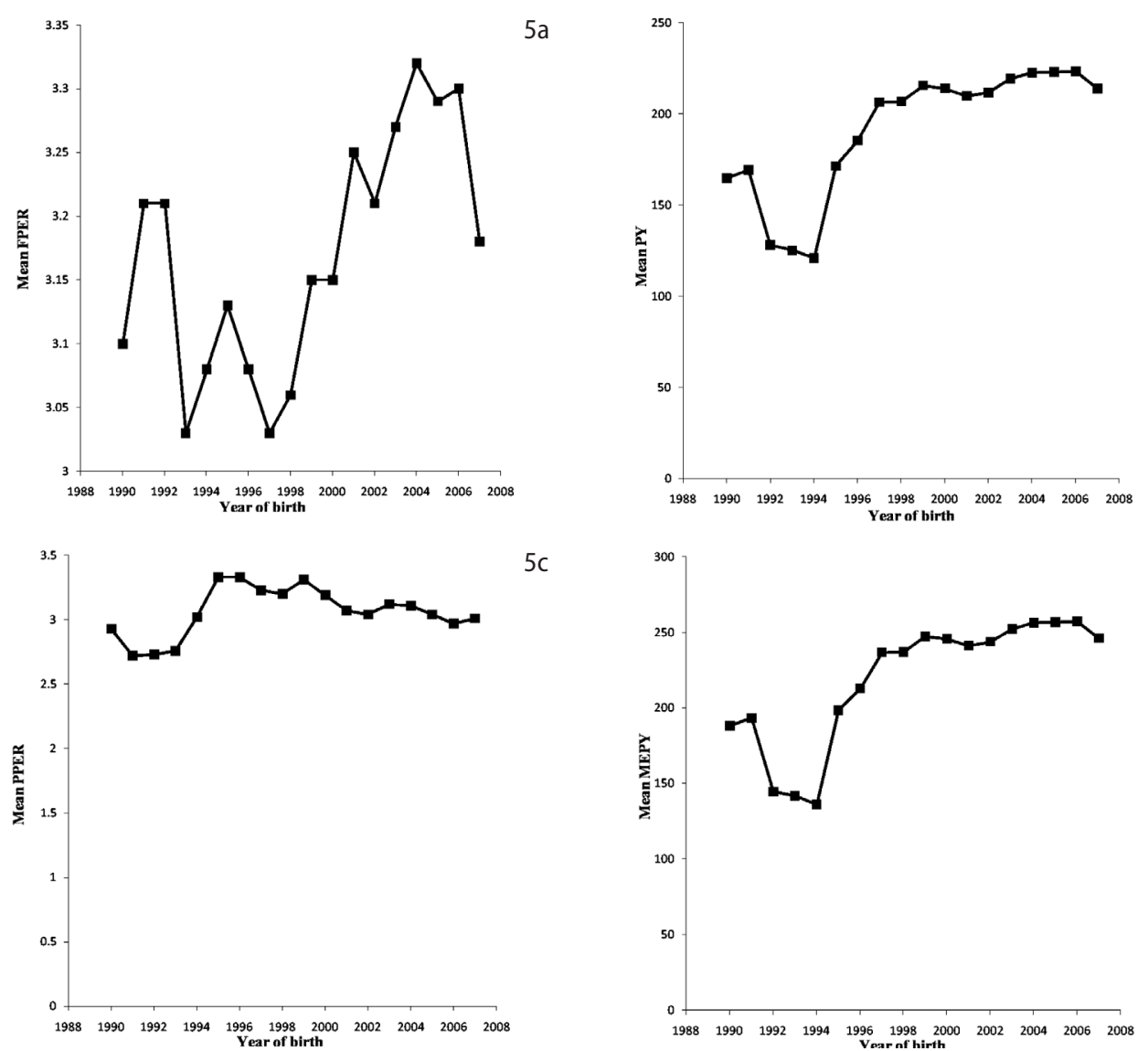

$5 c$

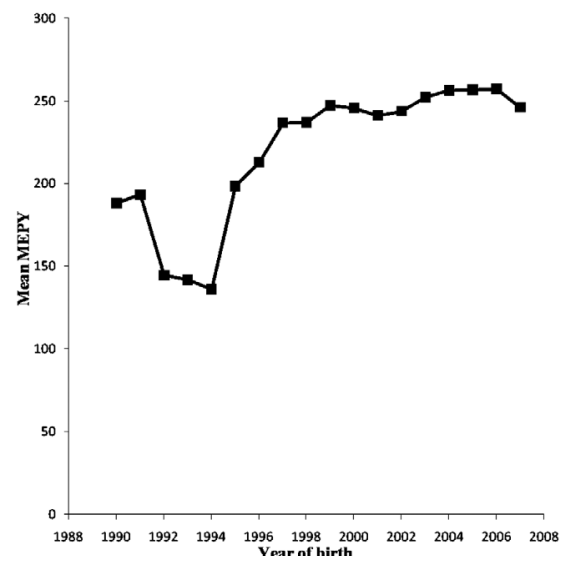

Figure 5

Phenotypic trends of FPER (5a), PY (5b), PPER (5c) and MEPY (5d) by year of birth in Holstein dairy cows

of superior genetic value than those used in the earlier years. Peixoto et al. (2006) reported the annual genetic trend in estimated breeding values of cows for 305- $d$ milk yield was $7.09 \pm 0.71 \mathrm{~kg}$ between 1987 and 2004, and 6.47 $\pm 2.35 \mathrm{~kg}$ between 1997 and 2004 in Guzerat herds. Estimate of genetic trend for milk yield in this study $(4.2 \mathrm{~kg} / \mathrm{year})$ was lower than the reports of Peixoto et al. (2006), Abdallah \& McDaniel (2000). Also, current estimate of genetic trend for milk yield was lower than the $13.88 \mathrm{~kg} /$ year obtained by Verneque et al. (1996) for the Gyr breed in Brazil. The lower estimates of genetic trends for yield traits in the current study compared to other reports can be attributed to the continuous entry of new sires and cows in the milk recording program, a more advanced age at first calving and the long calving interval, as well as the low frequency of use of sires proven and positive for milk yield. Some of these aspects are related to dairy operations such as fulfilment of nutritional needs and diet formulation, and milking management (Akers 2000). On the other hand, increasing trend for yield traits over time in this study indicated that Iranian dairy producers were successful in choosing progressively better semen and sires from 
imported and local sources over the years. It seems that dairy producers in Iran benefited from genetic trends for milk traits in the US and Canadian Holstein populations because $60 \%$ to $80 \%$ of semen used for artificial insemination in Iranian dairy herds is usually of US and Canadian proven sires (Ghavi Hossein-Zadeh et al. 2009).

In conclusion there were decreasing genetic trends for AFC, fat percentage and protein percentage over the years in general but there were increasing genetic trends for milk yield, mature-equivalent milk yield, fat yield, mature-equivalent fat yield, protein yield and mature-equivalent protein yield over the years. On the other hand, there was a decreasing phenotypic trend for AFC but estimates of phenotypic trends were positive for milk yield and compositions over the years. Estimates of yield traits in this study were lower than those of other reports but increased trend for yield traits over time indicated that Iranian dairy producers were successful in choosing progressively better semen and sires from imported and local sources over the years. On the other hand, decreased genetic and phenotypic trends for AFC resulted primarily from increased turnover rate and increased culling of heifers that failed to get pregnant. Also, the decreases in AFC might represent earlier maturity from better calf-raising practices or from intense selection for high milk yield during the first parity.

\section{References}

Abdallah JM, McDaniel BT (2000) Genetic parameters and trends of milk, fat, days open, and body weight after calving in North Carolina experimental herds. J Dairy Sci 83, 1364-1370

Akers RM (2000) Selection for milk production from a lactation biology viewpoint. J Dairy Sci 83, 1151-1158

Bewley J, Palmer RW, Jackson-Smith DB (2001) Modeling milk production and labor efficiency in modernized Wisconsin dairy herds. J Dairy Sci 84, 705-716

Dobos RC, Nandra KS, Riley K, Fulkerson WJ, Alford A, Lean IJ (2004) Effects of age and live-weight of dairy heifers at first calving on multiple lactation production. Aust J Exp Agric 44, 969-974

Dürr JW, Monardes HG, Cue RI (1999) Genetic analysis of herd life in Quebec Holsteins using Weibull models. J Dairy Sci 82, 2503-2513

Elzo MA, Jara A, Barria N (2004) Genetic parameters and trends in the Chilean multibreed dairy cattle population. J Dairy Sci 87, 1506-1518

Ettema JF, Santos JE (2004) Impact of age at calving on lactation, reproduction, health, and income in firstparity Holsteins on commercial farms. J Dairy Sci 87, 2730-2742

Ghavi Hossein-Zadeh N, Nejati-Javaremi A, Miraei-Ashtiani SR, Kohram H (2009) Estimation of variance components and genetic trends for twinning rate in Holstein dairy cattle of Iran. J Dairy Sci 92, 3411-3421

González-Recio O, Pérez-Cabal MA, Alenda R (2004) Economic value of female fertility and its relationship with profit in Spanish dairy cattle. J Dairy Sci 87, 3053-3061

Hare E, Norman HD, Wright JR (2006) Trends in calving ages and calving intervals for dairy cattle breeds in the United States. J Dairy Sci 89, 365-370

Katkasame S, Tumwasorn S, Thanindratarn B, Pasanpanich S (1996) Trend analysis on milk production traits in the dairy farming promotion organization of Thailand. Kasetsart J, Nat Sci 30, 211-219

KNRS $=$ Koninklijk Nederlands Rundvee Syndicaat (2005) Annual statistics 2004. Coöperatie Rundveeverbetering Delta, Arnhem, The Netherlands [in Dutch]

Mahoney CB, Hansen LB, Young CW, Marx GD, Reneau JK (1986) Health care of Holsteins selected for large and small body size. J Dairy Sci 69, 3131-3139

Michailowskaja A, Mielenz N, Schüler L, Bergfeld U, Müller U (2001) Estimation of genetic parameters in the dairy cattle population of Saxonia. Arch Tierz 44, 589-597 [in German] 
Mohsen MK, Tawfik ES, Salem AY, El-Awady HG (2000) Study on Friesian herds raised in Egypt and Germany II. Genetic and phenotypic trends in estimated transmitting ability. Arch Tierz 43, 399-410

Nilforooshan MA, Edriss MA (2004) Effect of age at first calving on some productive and longevity traits in Iranian Holsteins of the Isfahan Province. J Dairy Sci 87, 2130-2135

Ojango JMK, Ducrocq V, Pollott GE (2005) Survival analysis of factors affecting culling early in the productive life of Holstein-Friesian cattle in Kenya. Livest Prod Sci 92, 317-322

Peixoto MGCD, Verneque RS, Teodoro RL, Penna VM, Martinez ML (2006) Genetic trend for milk yield in Guzerat herds participating in progeny testing and MOET nucleus schemes. Genet Mol Res 5, 454-465

Pirlo G, Miglior F, Speroni M (2000) Effect of age at first calving on production traits and on difference between milk yield returns and rearing costs in Italian Holsteins. J Dairy Sci 83, 603-608

SAS (2002) User's Guide: Statistics, Version 9.1. SAS Inst. Inc., Cary, NC, USA

Sawa A, Bogucki M (2010) Effect of some factors on cow longevity. Arch Tierz 53, 403-414

Sawa A, Krężel-Czopek S (2009) Effect of first lactation milk yield on efficiency of cows in herds with different production levels, Arch Tierz 52, 7-14

Tozer PR, Heinrichs AJ (2001) What affects the costs of raising replacement dairy heifers: a multiple-component analysis. J Dairy Sci 84, 1836-1844

USDA (2002a) Dairy 2002. Part I: Reference of dairy health and management in the United States, 2002. Rep. N377.1202. National Animal Health Monitoring System, Animal and Plant Health Inspection Service, USDA, Fort Collins, $\mathrm{CO}$

USDA (2002b) Dairy 2002. Part II: Changes in the United States dairy industry, 1991-2002. Rep. N399.0603. National Animal Health Monitoring System, Animal and Plant Health Inspection Service, USDA, Fort Collins, CO

Vergara OD, Elzo MA, Cerón-Muñoz MF (2009) Genetic parameters and genetic trends for age at first calving and calving interval in an Angus-Blanco Orejinegro-Zebu multibreed cattle population in Colombia. Livest Sci 126, 318-322

Verneque RS, Ferreira WJ, Teodoro RL, Martinez ML (1996) Tendência genética da produção de leite em rebanhos da raça Gir leiteiro. Anais da 33a Reunião Anual da Sociedade Brasileira de Zootecnia, Fortaleza, CE, Brazil, 30-32

Wang T, Fernando RI, Kachman DS (2001) MATVEC User's Guide. Department of Biometry. University of Nebraska, USA

Received 10 October 2010, accepted 9 February 2011.

Corresponding author:

Navid Ghavi Hossein-Zadeh

email: nhosseinzadeh@guilan.ac.ir or navid.hosseinzadeh@gmail.com

Department of Animal Science, Faculty of Agriculture, University of Guilan, Rasht, P. O. Box: 41635-1314, Iran 